\title{
Correlation Between Function-Morphology of Effect of the Stress and Flunitrazepam Administered During Gestation in Adult Mouse Ovary
}

\author{
Correlación Entre la Función y la Morfología de los Efectos de Estrés \\ y Flunitrazepam Administrado Durante la Gestación en Ovario de Ratón Adulto
}

\author{
Ana Julia Aguirre-Samudio; Graciela de la Fuente-Juárez; Amalia Márquez-Orozco \& María Cristina Márquez-Orozco
}

AgUIRRE-SAMUdio, A. J.; DE LA FUENTE-JUÁREZ, G.; MÁRQUEZ-OROZCO, A. \& MÁRQUEZ-OROZCO, M. C. Correlation between function-morphology of effect of the stress and flunitrazepam administered during gestation in adult mouse ovary. Int. J. Morphol., 28(1):309-316, 2010.

SUMMARY: Previously we report long lasting effects on ovary of mice prenatally exposed to flunitrazepam (FNZ), a benzodiazepine with tranquilized action. In this work we find that the FNZ don't prevent the effects on ovary prenatally exposure to stress in mice. We studied adult females born from mothers that had been stressed by immobilization on day 6 ofgestation (GD-6) or group S, and from mothers stressed also by immobilization at GD-6, but which received a single oral dose of FNZ immediately after the stress group FNZS. The control groups were the SS that received the GD-6 saline solution and the group NT non-treated. Their ovaries were extracted for histology studies and to observe the activity of $3 b$ hydroxysteroid dehydrogenase/isomerase ( 3 b-HSD). The histological analysis revealed high staining affinity ovarian cell of S and FNZS. Double oocytes and apoptotic bodies were found in the secondary atretic follicles, as well as abnormal primordial, primary and secondary follicle populations, as compared to SS and NT groups. The primordial, primary, and secondary follicles were significantly reduced in the experimental groups. But the primary and secondary atretic follicles were higher in both groups, and the number of corpora lutea was lower in both groups. The activity of 3 b-HSD was abnormally increased in both FNZS- and S-groups. These findings suggest that FNZ did not counteract the impairing effects of prenatal stress on adult offspring ovarian follicles, and could rather be responsible for long lasting changes occurring during embryonic programming.

KEY WORDS: Benzodiazepine, 3 b-HSD, Flunitrazepam, Mouse, Ovaries, Atretics follicles, Prenatal stress.

\section{INTRODUCTION}

Prenatal stress (PS) environments exert profound influences on the development of an organism in many species (Reznikov et al., 1999), including humans, and could predispose for adaptive disturbances in later life. Stress, as a state of threatened homeostasis in the organism, is a condition reestablished by the complex group of physiological adaptative and behavioral responses (Chrousos, 1995; Pecke \& Chrousos, 1995), i.e., a survival and evolutionary mechanism. The stress system is governed through the corticotropine-releasing hormone ( $\mathrm{CRH})$ and the hypothalamic-pituitary-adrenal cortex axis (HPA) (Stratakis and Chrousos, 1995). For instance, in adult nonhuman primates, exposed to early-life stressors, show persistent elevations in cerebrospinal fluid concentrations of CRH (Coplan et al., 1996). The stress response can affect the reproductive function in multiple ways (Rabin et al., 1988).
Therefore, CRH and other factors of the stress system are associated with the hypothalamic-pituitary-gonadal axis (HPG), which inhibits hormonal release (Calogero et al., 1996, Petraglia et al., 1987) and ovarian steroidogenesis, and might be actively involved in follicular atresia and luteolysis (Ghizzoni et al., 1997).

Besides, 3 beta-hydroxysteroid dehydrogenase/ isomerase ( $3 \mathrm{~b}$-HSD), an enzyme that catalyses the conversion to the progesterone-like precursor of gonadal steroids, is depleted by PS during development of fetal testis, inducing alterations in fetal testicular function and sexual differentiation (Pollard \& Dyer, 1985). Indeed, long term PS effects result in reduced fertility and fecundity, delay of sexual maturation, changes in the estrous cycle, moderate increase of adrenocortical response to acute stress (Reznikov 
et al., 1999), as well as in altered reproductive behavior of adult female offspring (Frye \& Orecki, 2002).

On the other hand, benzodiazepines (BDZs) are used for the treatment of anxiety; among them, flunitrazepam (FNZ) is used as myorelaxing, preanesthetic agent, and as anxiolytic to reduce the effects of fear, anxiety, and stress. For example, prenatal treatment with diazepam (DZ) a BDZ, totally counteracts the effect of stress on behavior, normalizing the time-course of neonatal reflexes and the behavioral responses in adulthood, but it can also induce body growth retardation (Drago et al., 1999). In our laboratory, we have demonstrated that DZ administered to pregnant mice causes teratogenic effects in the offspring, such as histological alterations in the mesencephalon, the bone, and the testicles (Márquez Orozco et al., 1998; De la Fuente-Juárez et al., 1998; Mata Santibañez et al., 1993).

FNZ crosses easily the placental barrier (McAlister, 1980; Kanto et al., 1987) and is a ligand of the peripheral benzodiazepine receptor (PBR), which is ubiquitous, and of the central benzodiazepine receptor associated to GABA in the brain (Parola et al., 1993). In a previous work (Aguirre $e t$ al., 2006) we reported a decrease in normal ovary follicles and an increase in the number of atretic follicles in mouse treated with FNZ during gestation. The purpose of the present work is to describe the effects of acute PS on the ovarian follicles and the corpus luteum, and to examine whether FNZ administered on gestation day 6 (GD-6), just after the stress, can reverse the PS effects, generating normal growth and ovarian development.

\section{MATERIAL AND METHOD}

Animals: Experiments reported here were conducted in accordance with the 1985 Animal Protection Act (Code of Ethics on Animal Experimentation, Stocockolm, Sweden ), and following Mexican regulations on Animal Care with approval of the Ethics Committee of the School of Medicine, UNAM. Samples were obtained from strain ICR mice (Harlan Sprague Dawley, Indianapolis, USA). Twelve virgin female mice were mated with four experimental males of the same strain and age. In the experiment, firstly the pregnant females were divided in four groups on day 6 of gestation (GD-6). The first group $\mathrm{S}$ was subjected to stress by immobilization during 3 hours in the morning. The second group FNZS was stressed the same way, but was administered a single oral dose of $2.5 \mathrm{mg} / \mathrm{kg} / \mathrm{bw}$ of FNZ (Productos Roche®, S.A de C.V. Toluca, México) (equivalent to human doses) just after the stress. Two control groups were formed; one SS received orally in GD-6 0.9\% saline solution and the group NT non treated.
During the postpartum period, mice were left to nurse and were distributed in four groups, each one with the pups prenatally treated. Animals were kept under a 12:12 photoperiod in pathogen-free environments; food (Teklad LM-485, Harlan México, D.F., México) and water were provided ad libitum. The female litters that reached adulthood were killed by cervical dislocation during early estrous, which was evaluated through vaginal cytology.

Histological procedure: Ovaries were extracted and fixed in Zenker's solution and embedded in Paraplast for serial sections $(5 \mu \mathrm{m})$. Sections of the medullary area were stained with hematoxylin-eosin and observed under light microscopy. The classification of healthy and atretic follicles has been previously described (Aguirre-Samudio et al., 2006). Too, we identified the corpus luteum as the tissue with luteal cells, shaped polyhedrally, and surrounded by small blood vessels. The healthy primordial, primary, and secondary follicles, as well as the atretic follicles, were quantified. In the corpus luteum, luteal cells were counted per $1 \mathrm{~mm}^{2}$ of each ovary.

The steroidogenically active ovary cells were identified histochemically through detection of $3 \beta$ hydroxysteroid dehydrogenase/isomerase (3ß-HSD) activity as described previously (Duleba et al., 1997) with some modifications. $5 ß$-androstan-3ß-ol-17-one served as substrate for 3ß-HSD; blue staining of the cells resulted from the subsequent redox reaction with nitroblue tetrazolium. The tissue was fixed with $10 \%$ neutral formalin for $10 \mathrm{~min}$, washed and stained with methyl green. Slides mounted with stained (steroidogenically active) and nonstained cells (steroidogenically inactive) were observed under microscopy. Prior to tissue observation, the samples were randomized and the observer was blinded to the treatment. Besides, we used testis tissue with sterodogenically active cells (Pollard \& Dyer, 1985) as positive control.

Statistical analyses: The quantitative and qualitative variables of the experimental and control groups were assessed through Kruskal Wallis and U Mann Whitney tests; level of significance was set at $\mathrm{p}<0.05$. Results are presented as the mean \pm standard error.

\section{RESULTS}

Mothers and their pups were weighed, no differences among groups were observed. The number of pups for evaluation was variable, because many were dead at birth, particularly those from the $\mathrm{S}$ group. 

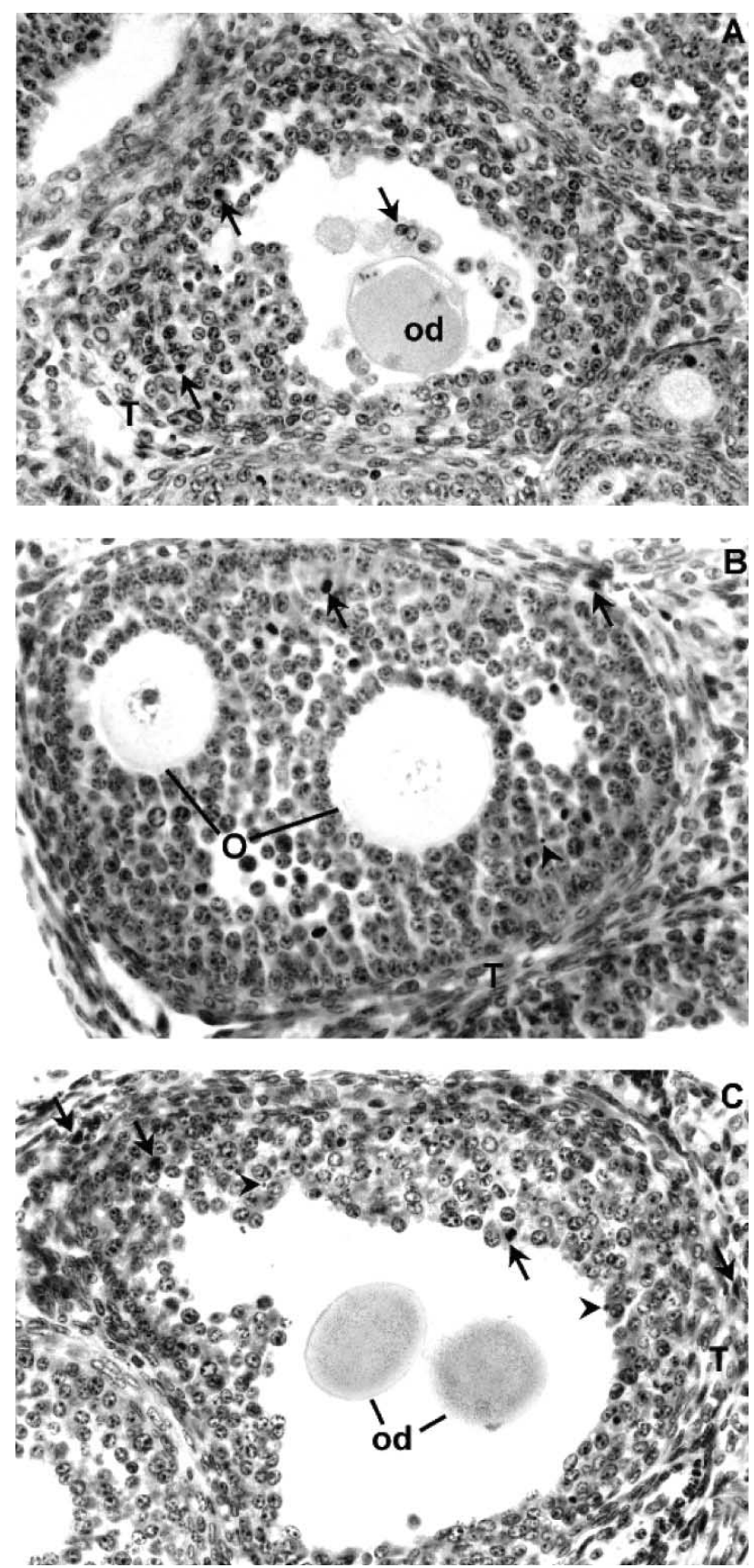

Fig. 1. Effect of stress and flunitrazepam (FNZ) on postnatal ovaries. Ovaries were collected from 62 days old mice, their mothers had been treated with stress and FNZ on the 6th of gestation. Each section was evaluated for morphological appearance of secondary atretic follicles. a) ovary of a control, the oocyte is degenerated (od). b) ovary of offspring subjected to prenatal stress by immobilization. Observe two oocytes (o) in the same follicle. c) ovary of offspring treated with prenatal stress and FNZ. Some cells have morphological features of apoptosis in the zona granulosa or theca cells (T), such as cells with small nucleus and dense chromatin (arrows) or cells with densely stained nuclear fragments (arrowheads). Original magnitude X40.
The gross ovarian anatomy of the offspring from mothers with $\mathrm{S}$ and FNZS treatments revealed no differences with respect to the controls; however the FNZS ovaries often were smaller than in the other groups. All ovaries had welldeveloped follicles, atretic follicles, and corpora lutea. However, some atretic follicles with double oocytes were observed in the stressed groups, a characteristic not found often in mice (Figs. 1b, 1c). High stain affinity of the granulosa cells of healthy follicles, atretic follicles, and of the corpus luteum cells were clearly evident in both experimental groups (Figs. 1b, 1c). Nuclear fragments were evident in the zona granulosa, follicular antrum, and theca cells of atretic secondary follicles and corpora lutea. There were also, cells containing pyknotic nuclei, abundant heterochromatin or marginal chromatin with multiple smaller, densely stained, nuclear fragments (Figs. 1a-c) in the S and FNZS groups.

The corpus luteum cells of the S and FNZS groups contained abundant cytoplasm with vacuole-like structures and this characteristic was disseminated throughout the cells (Fig. 2b, 2c), besides showing a reduced nuclear size.

The number of follicles is summarized in Table I. The healthy follicles were significantly decreased in the $S$ and FNZS $(\mathrm{p}<0.01)$ groups with respect to controls. The secondary follicles were decreased in S and FNZS groups $(\mathrm{p}<0.01)$ and there was a significant increment in primary atretic follicles in $\mathrm{S}$ and FNZS $(\mathrm{p}<0.001)$ groups in contrast to the control groups. The mean amount of secondary atretric follicles revealed an increasing tendency in the $S(p=0.04)$ and FNZS $(\mathrm{p}<0.01)$ groups as compared to controls.

The number of corpora lutea per ovary in the $\mathrm{S}$ and FNZS groups were reduced and the mean number of luteal cells per field were decreased in the $S$ mice, $(p=0.01)$, as compared to controls. There were no differences between the FNZS group $(\mathrm{p}=0.22)$ and the controls.

To confirm 3b- HSD activity, we used testis tissue as positive control. Representative experiments are presented in Figure 3. Theca-interstitial cells and the corpus luteum showed more 3b- HSD activity in the FNZS and S groups. 3b- HSD activity was also low in granulosa cells from all groups, except for granulosa cells of atretic follicles (data no shown) that formed cumuli.

\section{DISCUSSION}

After administering FNZ to pregnant stressed mice, adult offspring showed increased follicular atresia in ovaries and alterations in cells associated with a high affinity label 

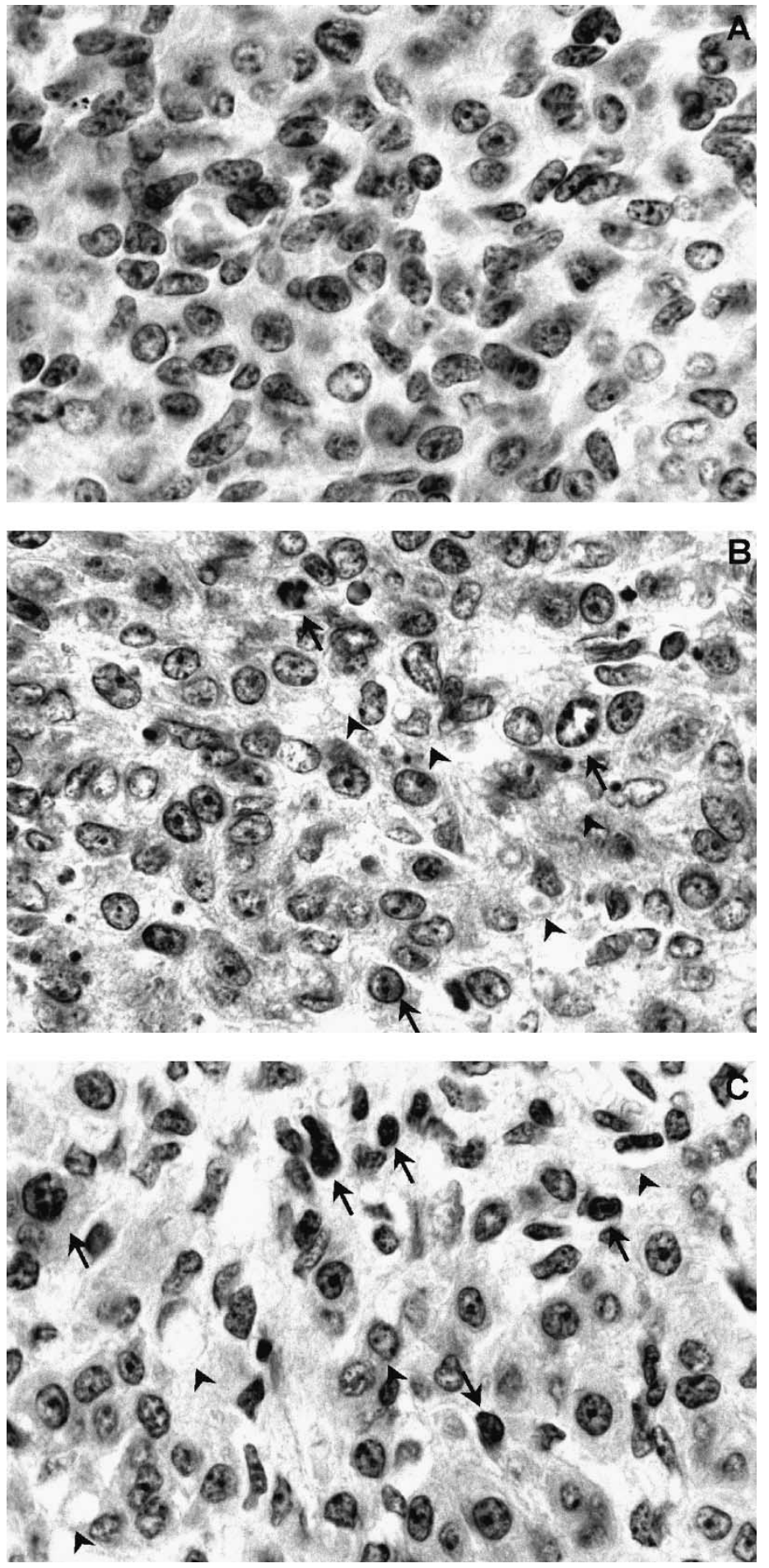

Fig. 2. Effect of prenatal stress (PS) and flunitrazepam (FNZ) on luteal cells pf breeding mice. Ovary tissues of control mouse (a). Arrowhead denotes cytoplasm with vacuole-like appearance in mice subjected to PS or PS plus FNZ application (b and c). Straight arrows indicate cells with big compacted or marginated chromatin. Tissue was fixed in Zenker's solution and stained with hematoxylineosin. Original magnitude X100. in nuclei and vacuolar cytoplasmic. In a previous report, we showed that FNZ induces an increase in follicular atresia in ovaries when administered during gestation (Aguirre et al., 2006). Our results suggest an effect by both treatments, i.e., FNZ effect could have been added to the stress effect instead of eliminating it, since both factors act on the direct regulation of the HPG axis through the HPA axis. This agrees with a previous report in which diazepam, another benzodiazepine, was not effective in reducing stress-induced corticosterone levels (Kalman et al., 1997). Similar structures found in this work have been reported to be part of the alterations in cytoplasmic organelles, chromatin, mitosis, and cellular differentiation that could be effects of a BDZ (DZ) treatment during pregnancy (Márquez-Orozco et al., 1998). Notably, in our preparations, an advanced chromatin condensation was observed, which is similar to that found in neuronal nuclei identified in brains of embryos, whose mother had been subjected to a short-term emotional-painful stress (Diuzhikova et al., 2000). Plehn-Dujowich et al., (2000) have demonstrated in vitro that stress induced chromatin condensation, which it is different from necrosis process, nuclear mitosis or apoptosis leads. In fact, chromatin itself could be a target in the cellular response to physiological and toxicological stimuli (Moggs \& Orphanides, 2004).

Because ovarian follicular degeneration is a hormonally controlled apoptotic process (Kaipia and Hsueh, 1997), in our experiments, animals were selected in estrus to avoid hormonal cycling interfering with the results. It is knowledge that $\mathrm{CRH}$ alter ovarian hormone, in fact, a previous work showed that immobilization stress induces a marked expression of CRH messenger RNA in stroma cells that differs during the gonadal life cycle within the ovary (Nappi and Rivest, 1995).

In this study, the increase in atretic follicles could be explained in at least two ways. On one side, $\mathrm{CRH}$, which is known to suppress FSH-stimulated estrogen production from rat granulosa cells, decreases the sensitivity of granulosa cells to FSH (Calogero et al., 1996), suppresses basal estrogen production from luteal cells, and could act to decrease progesterone concentration in sera. On the other side, $\mathrm{CRH}$ inhibits LH secretion, suggesting that its deleterious effects on reproductive functions are exerted through brain sites (Rivier \& Vale, 1984). Hence, the follicular atresia in the experimental 

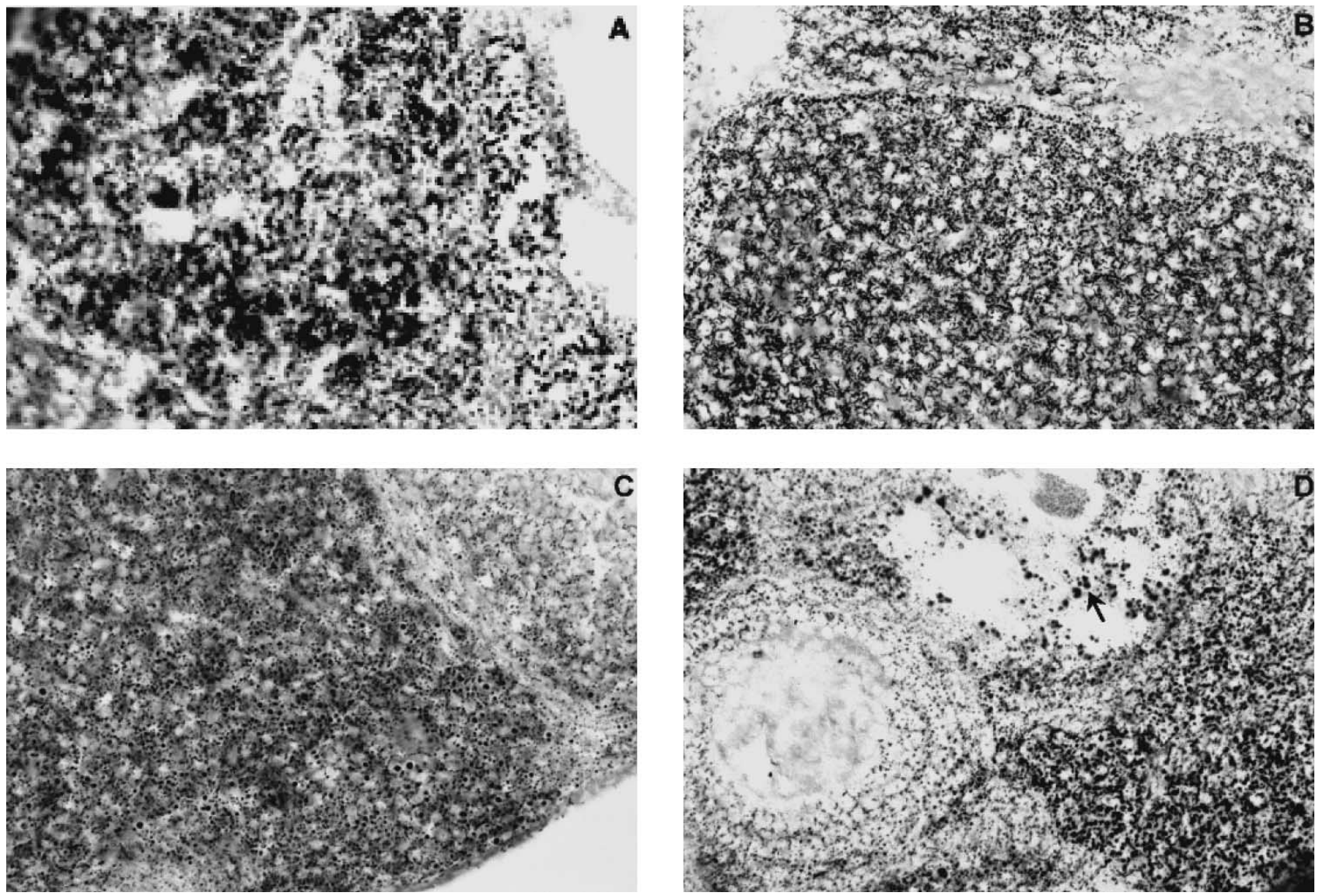

Fig. 3. Histochemical analysis of 3b-HSD activity from ovary tissue of mice. Corpora lutea of: a) control, b) ovary of adult mouse from a mother stressed during gestation, c) effect of flunitrazepam after prenatal stress in adult mouse, d) labeling of 3b-HSD in atretic follicle from mouse subjected to prenatal stress. Note preferential location of activity in granulosa cell aggregates (arrow). Representative photographs of four experiments. Original magnitude X40.

Table I. Morphometric analysis of follicles in ovaries of mouse, in estrus, exposed to prenatal stress and flunitrazepam

\begin{tabular}{lcccccc}
\hline Groups & Primordial & Primary & Secondary & Atretic $1^{\circ}$ & Atretric $2^{\circ}$ & $\mathrm{N}$ \\
\hline Controls & $15.8 \pm 1.1$ & $32.4 \pm 2.1$ & $9.1 \pm 1.1$ & $11.6 \pm 0.9$ & $10.2 \pm 3.5$ & 20 \\
FNZS & $8.6 \pm 0.97^{\mathrm{c}}$ & $14.3 \pm 1.5^{\mathrm{c}}$ & $4.1 \pm 0.97^{\mathrm{c}}$ & $27.0 \pm 2.5^{\mathrm{c}}$ & $20.0 \pm 2.6^{\mathrm{c}}$ & 14 \\
$\mathrm{~S}$ & $9.5 \pm 1.5^{\mathrm{c}}$ & $21.0 \pm 3.6^{\mathrm{b}}$ & $3.5 \pm 1.0^{\mathrm{b}}$ & $34.9 \pm 4.7^{\mathrm{c}}$ & $15.4 \pm 2.1 \mathrm{a}$ & 8 \\
Saline solution & $10.4 \pm 2.1$ & $32.6 \pm 6.8$ & $10.0 \pm 0.9$ & $10.0 \pm 1.3$ & $11.2 \pm 0.5$ & 5 \\
\hline
\end{tabular}

Types of follicles. Control (non-treated or with $0.9 \%$ saline solution); S: animals subjected to stress on the $6^{\text {th }}$ day of gestation; FNZE: oral administration of flunitrazepam after stress. Atretic $1^{\circ}$ : atretic primary follicles, Atretic $2^{\circ}$ : atretic secondary follicles. $\mathrm{p}<0.05^{\mathrm{a}}, 0.01^{\mathrm{b}}, 0.001^{\mathrm{c}}$

groups could suggest a disorder of the reproductive system that results in reduced fertility. Previously, Herrenkohl (1979) described the prenatal stress syndrome in female offspring as being characterized by estrous cycle disorders, spontaneous abortions, and vaginal hemorrhaging during pregnancy, stillbirths, and neonatal mortality, as well as low birth weight. In fact, exposure to uncontrollable stress during pregnancy results in elevated maternal and fetal plasma costicosteroid levels, affecting the fetal HPA axis directly and altering fetal growth and infants development and can exert deleterious effects on the whole body, brain, and sexual behavior (Edwards and Burham, 2001).

The conversion of pregnenolone to progesterone in the ovary is catalyzed by the enzyme 3b-hydroxy-steroid dehydrogenase isomerase (3b-HSD), essential for steroids 
AGUIRRE-SAMUDIO, A. J.; DE LA FUENTE-JUÁREZ, G.; MÁRQUEZ-OROZCO, A. \& MÁRQUEZ-OROZCO, M. C. Correlation between function-morphology of effect of the stress and flunitrazepam administered during gestation in adult mouse ovary. Int. J. Morphol., 28(I):309-316, 2010.

formation. We found that the stressed groups had higher $3 b-$ HSD activity in the corporea lutea area and internal theca cells, and lower activity in granulosa cells during the estrous cycle. The granulosa cells, lying near the antrum, usually displayed a weaker reaction than those in the mural region, this enzymatic activity correlates with previous studies (Tabarowski \& Szoltys, 1987), although, it is not known why 3b-HSD activity increases in adult subjects under stress and/ or in the ovary prenatally exposed to FNZ. Functionally, the modified 3b-HSD activity could contribute to the alterations in follicle development and could be correlated with the increased atretic follicles and decreased corpora lutea numbers due to treatment with stress and FNZ.

Our data reveal that FNZ administration to stressed mothers did not block the stress disorder in their pups; to the contrary, it increased the number of atretic follicles. In conclusion, our data suggest that PS and FNZ induce a cytotoxic effect by an increase in follicular atresia in the mouse ovary. This effect seems to be $3 b$ - HSD-dependent; however, it is indispensable to perform further studies to replicate these results in adult and fetal ovaries of mice.

AGUiRRE-SAMUdio, A. J.; DE LA FUENTE-JUÁREZ, G.; MÁRQUEZ-OROZCO, A. \& MÁRQUEZ-OROZCO, M. C. Correlation between function-morphology of effect of the stress and flunitrazepam administered during gestation in adult mouse ovary. Int. J. Morphol., 28(1):309-316, 2010.

RESUMEN: Previamente comprobamos efectos de larga duración sobre el ovario de ratones expuestos prenatalmente a flunitrazepam (FNZ), una benzodiazepina con acción tranquilizante. En este trabajo encontramos que el FNZ, no revierte los efectos producidos por la exposición prenatal a estrés. Estudiamos hembras adultas nacidas de madres que se estresaron por inmovilización el día 6 de la gestación (DG-6) o grupo S, y de madres estresadas también por inmovilización el DG-6, las que recibieron una sola dosis de FNZ inmediatamente después del estrés (grupo FNZS). Los grupos de control fueron el SS al que se le administró solución salina y el NT no tratado. Se extrajeron sus ovarios para su estudio histológico y para observar la actividad de delta 3b-deshidroxiesteroide dehidrogenasa/ isomerasa (3 b-HSD). El análisis histológico reveló una gran afinidad tintoreal en los ovarios de los grupos $\mathrm{S}$ y FNZS. En los ovarios de los ratones del grupo FNZS se encontraron en los folículos secundarios atrésicos ovocitos dobles y cuerpos apoptóticos así como una población mayor de folículos anormales primordiales, primarios y secundarios en comparación con los grupos SS y NT. Los folículos primarios y secundarios tuvieron una reducción significativa en los grupos experimentales pero los folículos atrésicos primarios y secundarios fueron más en ambos grupos y el número de cuerpos lúteos fue menor en ambos grupos. La actividad de 3 b-HSD aumentó de manera anormal tanto en los grupos FNZ y S. Estos hallazgos sugieren que el FNZ no contrarresta los efectos negativos del estrés prenatal sobre los folículos ováricos de las crías adultas, y podría ser responsable de los cambios largo plazo que ocurren a durante la programación embrionaria.

PALABRAS CLAVE: Benzodiazepinas, 3 b-HSD, Flunitrazepam, Ratón, Folículos ováricos atrésicos, Estrés prenatal.

\section{REFERENCES}

Aguirre-Samudio, A. J.; De la Fuente-Juárez, G.; MárquezOrozco, A. \& Márquez-Orozco, M. C. Histological changes of the ovary of adult mice exposed prenatally to flunitrazepam. Int. J. Morphol., 24:651-8, 2006.

Calogero, A. E.; Burrello, N.; Negri-Cesi, P.; Papale, L.; Palumbo, M.; Cianci, A.; Sanfilippo, S. \& D’Agata, R. Effects of corticotropin-releasing hormone on ovarian estrogen production in vitro. Endocrinology, 137:41616, 1996.

Chrousos, G. P. Stressors, stress, and neuroendocrine integration of the adaptative response. Ann. N.Y. Acad. Sci., 771:311-35, 1995.

Coplan, J.; Andrews, M.; Rosenblum, L.; Owens, M.; Riedman, F. S.; Gorman, J. \& Nemeroff, C. Persistent elevation of cerebrospinal fluid concentrations of corticotropin-releasing factor in adult nonhuman primates exposed to early-life stressors: implications for the pathophysiology of mood and anxiety disorders. Proc. Natl. Acad. Sci. USA., 93:1619-23, 1996.

Cowan, K. J.; Diamond, M.I. \& Welch, W. J. Polyglutamine protein aggregation and toxicity are linked to the cellular stress response. Hum. Mol. Genet., 12:1377-91, 2003.

De la Fuente-Juárez, G.; Márquez-Orozco, M.C. \& MárquezOrozco, A. Persistent alterations in ossification in adult mice prenatally treated with Diazepam. Proc. West. Pharmacol. Soc., 41:187-8, 1998.

Diuzhikova, N. A.; Vaido, A. I.; Lopatina, N. G.; Mironov, 
S.V. \& Dudkin, K.N. Effect of prenatal emotional-pain stress on the status of interphase chromatin in neurons of the rat developing brain with various excitation of the nervous system. Tsitologiia, 42:772-86, 2000.

Drago, F.; Di Leo, F. \& Giardina, L. Prenatal stress induces body weight deficit and behavioral alterations in rats: the effect of diazepam. Eur. Neuropsychopharmacol. 9:239-45, 1999.

Duleba, A. J.; Spaczynski, R. Z.; Olive, D. L. \& Behrman, H. R. Effects of insulin and insulin-like growth factors on proliferation of rat ovarian theca-interstitial cells. Biol. Reprod., 56:891-7, 1997.

Edwards, H.E. \& Burnham, W.M. 2001: The impact of corticosteroids on the developing animal. Pediatric. Res., 50:433-40, 2001.

Frye, C. A. \& Orecki, Z. A. Prenatal stress alters reproductive responses of rats in behavioral estrus and paced mating of hormone-primed rats. Horm. Behav., 42:472-83, 2002.

Ghizzoni, L.; Mastorakos, G.; Vottero, A.; Barreca, A.; Furlini, M.; Cesarone, A.; Ferrari, B.; Chrousos, G.P. \& Bernasconi, S. Corticotropin-releasing hormone (CRH) inhibits steroid biosynthesis by cultured human granulosa-lutein cells in a CRH and interleukin-1 receptor-mediated fashion. Endocrinology, 138:4806-11, 1997.

Herrenkohl, L. R. Prenatal stress reduces fertility and fecundity in female offspring. Science, 206:1097, 1979.

Kaipia, A. \& Hsueh, A. J. W. Regulation of ovarian follicular atresia. Annu. Rev. Physiol. 59:349-63, 1997.

Kalman, B. A.; Kim, P. J.; Cole, M. A.; Chi, M. S. \& Spencer, R. L. 1Diazepam attenuation of restrain stress-induced corticosterone levels is enhanced by prior exposure to repeated restraint. Psychoneuroendocrinolgy, 22:349-60, 1997.

Kanto, J.; Errkkola, R.; Kangas, L. \& Pitkänen, Y. Placental transfer of flunitrazepam following intramuscular administration during labor. Br. J. Clin. Pharmacol., 23:491-4, 1987.

Márquez-Orozco, M.C.; Márquez-Orozco, A.; De la Fuente-Juárez, G. \& Hernández-Alvarez, L.A. Long-lasting effects of prenatal exposure to Diazepam in mesencephalon of mice. Proc. West. Pharmacol. Soc. 41:189-91, 1998.
Mata-Santibañez, M.V.; Márquez-Orozco, A. \& MárquezOrozco, M. C. Testicular histological changes in mice after prenatal administration of diazepam. Proc. West. Pharmacol. Soc., 36:117-21, 1993.

McAllister, C. B. Placental transfer and neonatal effects of diazepam when administered to women just before delivery. J. Anesth., 52:423-7, 1980.

Moggs, J. \& Orphanides, G. The role of chromatin in molecular mechanisms of toxicity. Toxicol. Sci., 80:21824, 2004.

Nappi, R. E. \& Rivest, S. Stress-induced genetic expression of a selective corticotropin- releasing factor- receptor subtype within the rat ovaries: an effect dependent on the ovulatory cycle. Biol. Reprod., 53:1417-28, 1995.

Parola, A.; Yamamura, H. \& Laird, H. II. Peripheral-type benzodiazepine receptors. Life Sci., 52:1329-42, 1993.

Peeke, P. M. \& Chrousos, G.P. 1995: Hypercortisolism and obesity. Ann. N.Y. Acad. Sci., 771:665-75, 1995.

Petraglia, F.; Sutton, S.; Vale, W. \& Plotsky, P. Corticotropinreleasing factor decreases plasma luteininzing hormone levels in female rats by inhibiting gonadotropin-releasing hormone release into hypophysial-portal circulation. Endocrinology, 120:1083-8, 1987.

Plehn-Dujowich, D.; Bell, P.; Ishov, A.M.; Baumann, C. \& Maul, G. G. Non-apoptotic chromosome condensation induced by stress: delineation of interchromosomal spaces. Chromosoma., 109(4):266-279, 2000.

Pollard, I. \& Dyer, S. L. Effect of stress administered during pregnancy on the development of fetal testes and their subsequent function in the adult rat. J. Endocrinol. 107:241-5, 1985.

Rabin, D.; Gold, P.; Margioris, A. N. \& Chrousos, G. P. Stress and reproduction: physiologic and pathophysiologic interactions between the stress and reproductive axes. Adv. Exp. Med. Biol., 245:377-87, 1988.

Reznikov, A.G.; Nosenko, N.D. \& Tarasenko, L.V. Prenatal stress and glucocorticoid effects on the developing gender-related brain. J. Steroid Biochem. Mol. Biol., 69: 109-15, 1999.

Rivier, C. \& Vale, W. Influence of corticotropin-releasing factor on reproductive functions in the rat. Endocrinol., 114:914-921, 1984. 
AGUIRRE-SAMUDIO, A. J.; DE LA FUENTE-JUÁREZ, G.; MÁRQUEZ-OROZCO, A. \& MÁRQUEZ-OROZCO, M. C. Correlation between function-morphology of effect of the stress and flunitrazepam administered during gestation in adult mouse ovary. Int. J. Morphol., 28(I):309-316, 2010.

Stratakis, C. A. \& Chrousos, G. P. Neuroendocrinology and pathophysiology of the stress system. Ann. N. Y. Acad. Sci., 771:1-18, 1995.

Tabarowski, Z. \& Szoltys, M. Histochemical localization of delta 5-3 beta-HSDH activity in preovulatory rat follicles. Folia Histochem. Cytobiol., 25:149-53, 1987.

Correspondenceto:

María Cristina Márquez-Orozco

Departamento de Embriología

Facultad de Medicina

Universidad Nacional Autónoma de México

México 04510 D. F.

MÉXICO

Fax (+52) 55623-2156

Email: cmarquezor@gmail.mx

Received: 24-08-2009

Accepted: 27-09-2009 